\title{
On Becoming a Research Geek
}

\section{Paula Schumacher}

Paula Schumacher has been writing since she was taught to hold a crayon. First she learned her name (which is how her father knew who was writing on the walls in the closet upstairs), then sentences, short stories laden with angst, and poems filled with the quiet wonder of winter in Northern Michigan (the UP). In college, Paula studied engineering, journalism and languages. After she earned an MBA, she found her best fit (IT business analysis) and settled into a work/ life balance that included a semidisciplined writing routine. Today she is finishing up a speculative historical bildungsroman novel set in ancient Mesopotamia, listening to music and enjoying art more, and spending a wonderous amount of time with her partner, Linda, and extended family.

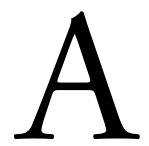

fter I had written my first novel, Hero's Quest Betrayed (a fantasy) in 2001, two events sowed the seeds for a transformation of my writing habit. The first was going to WisCon (a science-fiction convention with a feminist/social justice focus held in Madison, WI) and not only hearing Ursula Le Guin speak on writing but also having her answer my question "Was so much research really necessary?" with an emphatic yes.

The second event was being given Diana Wynne Jones' The Tough Guide to Fantasyland by my dear friend Virginia Ashlock (avid book reader, science editor, gardener, near miss on becoming my mother-in-law, and direct hit on being a great mentor in all areas). The book was an easy read and provided me feedback on writing fantasy in a nonthreatening, sarcastic yet humorous, manner.

Before these events, I relied solely on my own creativity and memory for world building. I didn't want to take the time for research I didn't believe was needed for a world I made up all by myself. As the Tough Guide indicated, I, like many fantasy writers, subconsciously relied on having read J. R. R. Tolkien's Hobbit and Lord of the Rings trilogy as the research for my worlds without figuring out much of the cultural, economic, or even environmental elements needed to bring a world to life.

As far as my memory, I was forever flipping back through my manuscript to find out how many gold pieces I said a tankard of ale, a bowl of stew, or a room at the inn cost. I also had a hard time keeping track of what I actually called things (because nothing tells a reader they're in a different world like calling boots "striders"). I wasn't consistent with terms and had to do a lot of cleanup. Virginia had drilled into me the need to be consistent. She often quoted Emerson's "Foolish consistency is the hobgoblin of little minds." She was an editor-so consistency in writing was never foolish to her way of thinking. (The full quote is "A foolish consistency is the hobgoblin of little minds, adored by little statesmen and philosophers and divines.")

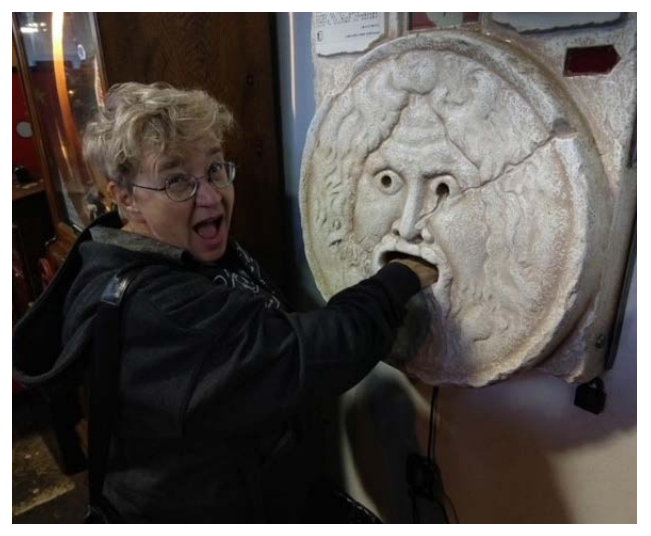

\section{ABSTRACT}

This article describes the research process involved in writing novels that provide historical contexts, materials, and characters. Writers will find this piece both humorous and helpful when considering all the planning needed to map out a novel.

\section{KEYWORDS}

research, beat sheet, novel writing 
My second book, Beginner's Guide to Office Boxing, was a foray into the realm of self-help. I did an extraordinary amount of research for it, mostly because psychology was not a world known to me-and also because I needed to be accurate.

The Glass Road, my third novel, was on its way to being a lawless mess when I remembered Le Guin's comment—and Virginia was giving me a hard time about flying by the seat of my pants. So, I dug in. That is what saved me from catastrophe.

This novel was going to be different, I told myself. To begin with, instead of writing what I wanted, I decided to take into consideration what the market wanted. I was playing a lot of bridge at the time, and I wanted to have card play as an element. There are many books on how to play bridge, but few have bridge as a plot device. I'm not an expert at the game; therefore, nobody would take seriously any book I wrote on playing bridge (and rightly so): I would write fiction. Genre wise, romance is not a good fit for serious bridge players. Neither, really, is science fiction, fantasy, or horror. Mystery seemed to make the most sense-especially since bridge players like to work things out (like how to win nine tricks when only seven seem possible). I know bridge players don't make for a huge market, but they are dedicated (and, I hoped, starved for light reading).

Once I decided on a mystery, I began to research requirements (such as word count). I learned that both the mystery and romance genres have set formulas. If you don't follow the formula, the odds of an agent or publisher accepting your manuscript are reduced. Obviously I wanted to be published, sell millions of copies, have a movie made, and maybe even get cool bling like coffee mugs with my sleuth on them. I searched the internet and found a great spreadsheet: Mystery Story Planning for Pantsers.

This breakdown of the mystery made everything possible! All I had to do was stuff all my ideas for the story into twelve chapters and edit to sixty-five thousand-like writing a sonnet (which I had tried my third year of college and have not wrestled into completion to this day).

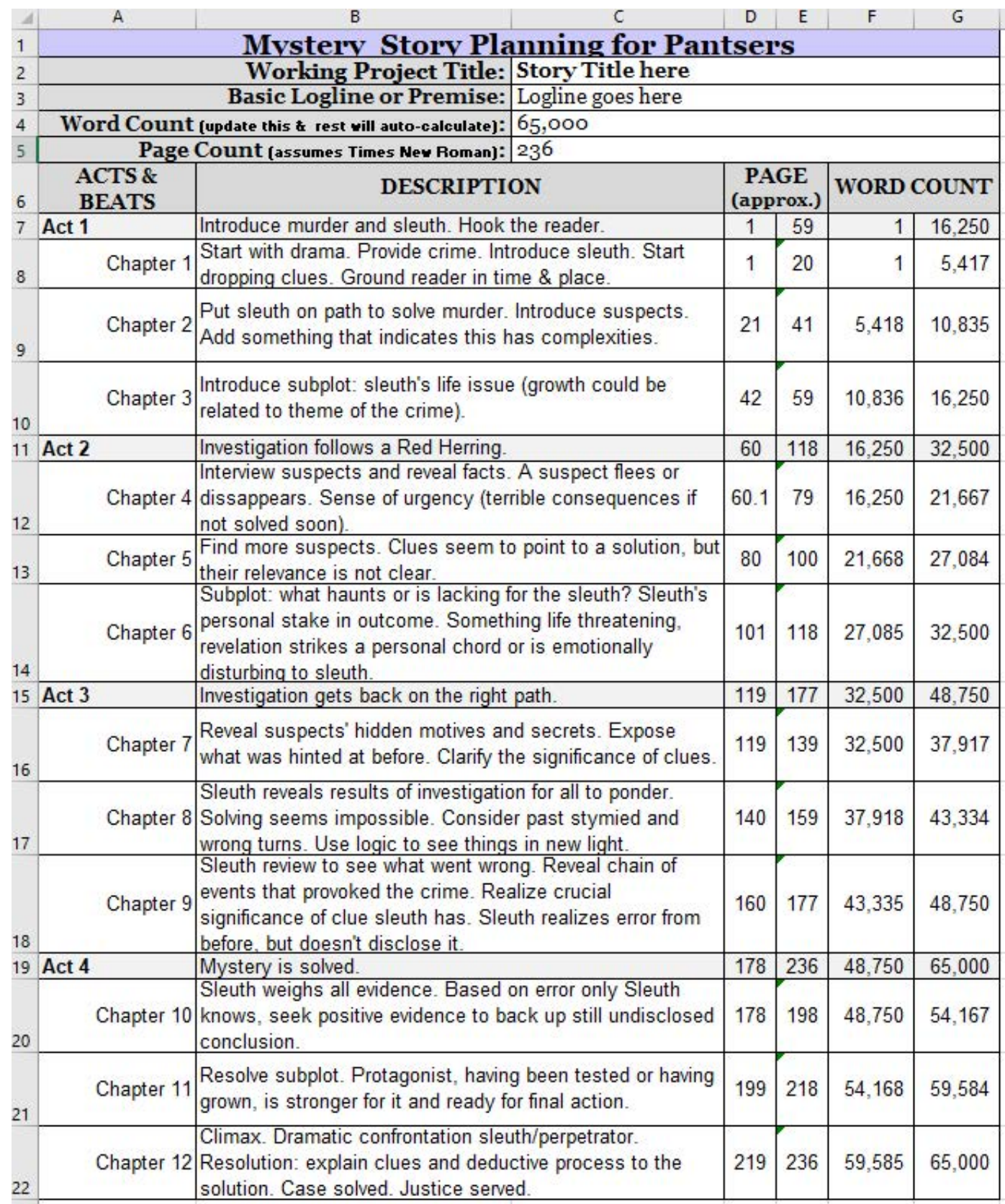


Next, I discovered NaNoWriMo (National Novel Writing Month) and improved my writing habit. A spreadsheet and headphones pumping club music over my internal critic's voice helped me write every day for a month.

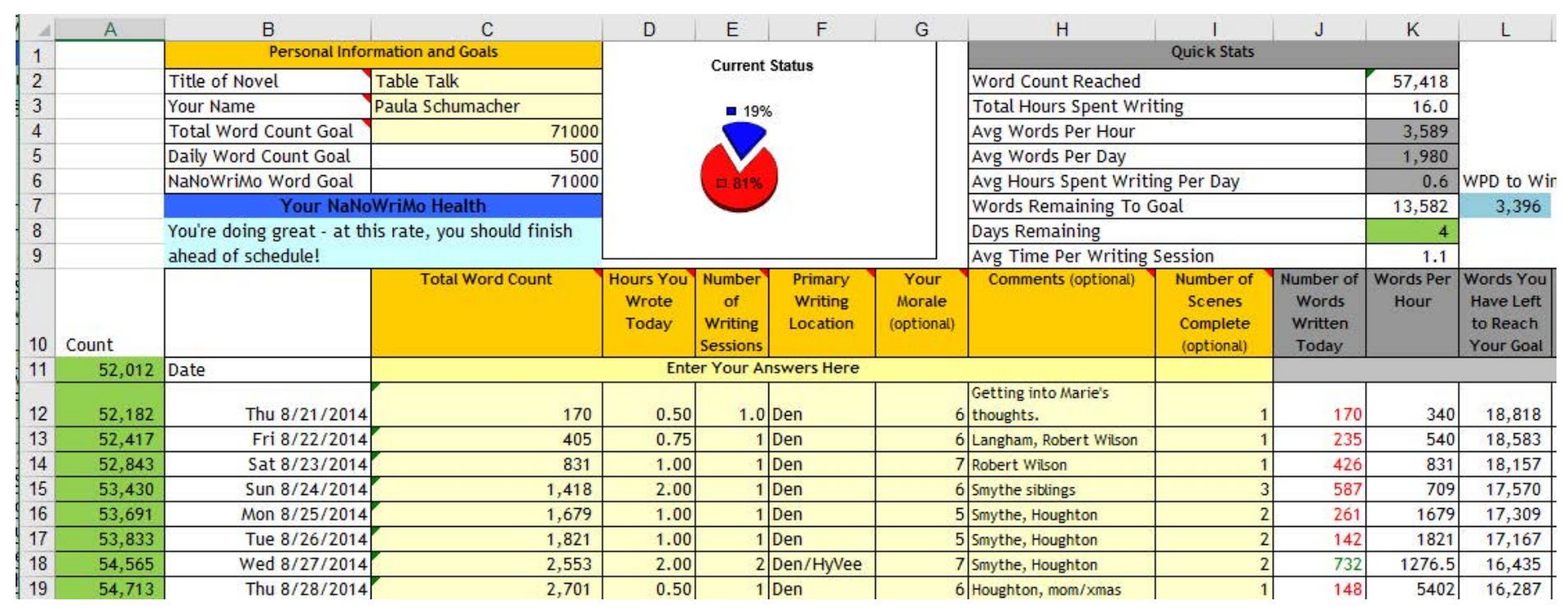

The beauty of NaNoWriMo for me is that there are no rules besides count every word. I gave myself permission to use the month to brainstorm characters and plot lines, to discover backstory, and to document all my research-everything. It's all one hot mess at the end of the month, but it's all there, and there is nothing several rounds of edits and rewrites won't fix.

Here's a sample from an early draft. I often lay down dialogue first, then come back in with tags, punctuation, the rest of the scene, etc., later. I also put in "notes to self" and highlight them. In the navigation pane you can see I created ad hoc chapters depending on what I wanted to write about that day.

Another change I made was to include friends and experts in my process. They helped me with ideas for character development, problems with plot, etc.

Once I decided to make my Sunday bridge group my card-playing plot device, I asked the Sunday players if they wanted to be portrayed as themselves or have a different life. The housewife wanted to be an international concert pianist but still have all her kids. The retired teacher wanted to be a piano bar/lounge performer. The gay scientist wanted a husband. The fourth player became the sleuth, so she didn't get to change her life but instead

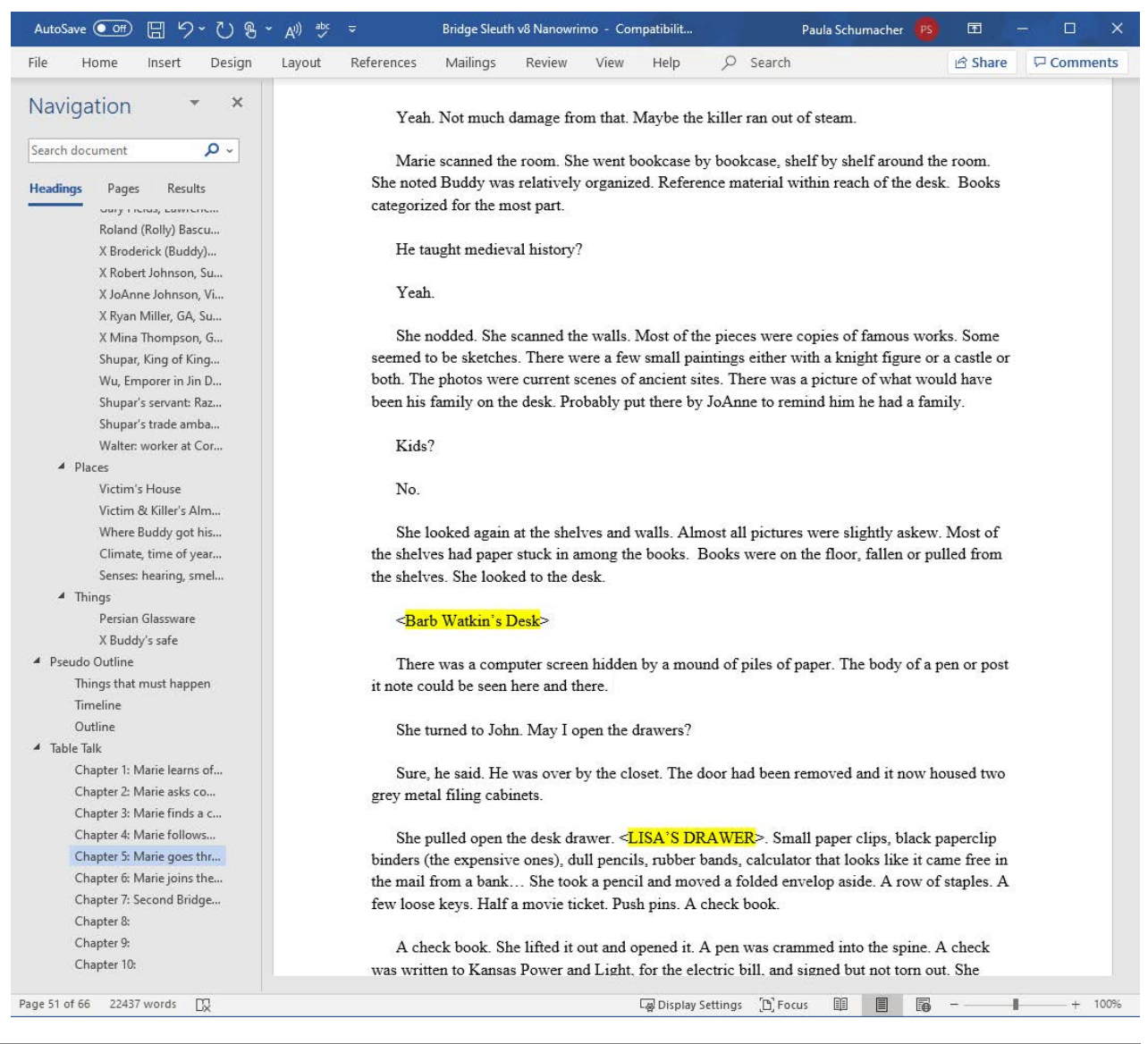


got peppered with my questions about her elegant style, etiquette, and eating habits. This made extra work for me, but the excitement it generated was worth it.

At a friend's afternoon party, I complained about defects in sleuths (all crime solvers must have inner demons). Alcoholism was overdone. OCD was getting to that point. Did anyone have an idea? We started brainstorming, and as soon as I heard about CAIS (complete androgen insensitivity syndrome), I knew it fit. Briefly, CAIS is where a person is male but his body is insensitive to testosterone, so his body develops with an outwardly female appearance. The condition is rare and is not usually figured out until either the "girl" doesn't start her menses or has severe pain thought to be a hernia (which is actually the testicles trying to descend). Historically, doctors performed an operation and told parents their little girl's ovaries were cancerous and had to be removed. As a writer, I thought "What a tormented person this would be if they ever found out the truth!" I researched the medical condition, contacted a CAIS support group, and watched documentaries.

Worried about writing a story in today's world (circa 2013), I started interviewing subject-matter experts like a museum curator, a detective, and a person with CAIS. Although I have a journalism degree and have interviewed people for news articles, I was worried that interviewing someone for a novel might seem frivolous. What I found is that if you are polite and explain yourself well, people are very willing to talk to you. The museum curator was hesitant to discuss theft, but once I explained the theft in my story occurred forty years ago and the items were being returned, she let go the fear that I was secretly casing the joint and shared her knowledge. Of course I had to keep track of my interviews in a spreadsheet.

\section{POLICE Q\&A EXCERPT}

4

101 . original theft

If the art is in a warehouse in the basement of a dorm, who all do the police interview? Warehouse workers? Dorm staff? Students

11 who live in the dorm?

12 How much of a report would you expect on the art theft? Will delaware let insurance company or KS police see the report?

13 Will it most probablv be a paper copv? Mavbe PDF?

14 Would university or local police handle the investigation?

15 Museum needs police report for insurance?

What kind of rap sheet would you expect for a small time bully like

16 Rollv? Disorderlv conduct? Intimidation. Possible small theft. Who has jurisdiction? Art from China, on loan from NY. Stolen from Delaware university museum (on campus). Even if it isn't your

17 jurisdiction, do vou lend manpower to the entity that does? How do you determine jurisdiction? (Laws) Can another police entity Where it occurs. And how (crosses country, etc.) come in and take over? Why? (because it's international issue?

18 Level of the crime?)

19

20 2. murder of Gus

If the killer travels from AZ to KS to confront the victim, then tempers rise during the confrontation and the killer kills the victim in rage (hit with statue, then suffocates), will that be voluntary

21 manslaughter or murder?

Call comes in around 0900 Monday morning in October. Grad student has found professor dead in house. Deceased is face up in den, pillow over face. Some signs on struggle (things in disarray).

22 Possiblv cuts, blood, on victim. Who responds?

23 Interview neighbors, co-workers, G.A.s, family?

Verify these suspects are valid: family (siblings, brother in law),

24 finder, arad student, odd ICE?

25 How do Lawrence Police interview a suspect in another state?

26 What does it take to get extradition? How long?

27 What does it take to get a warrant for arrest? How long?
B

Goes out from center. Keep adding to list, prioritize who to interview, then keep interviewing if no leads are uncovered.

A full box. Especially if was big news.

Yes. Will be paper.

University would have the lead, but would welcome help. Yes.

Would FBI lend support? Staff? Labs? Do you readily accept help? Yes, accept help. 
The mystery quickly got out of hand. Whereas with fantasies I worried about names and costs of things, now I had clues and answers and timelines and many, many more people. I had to get organized.

I tracked my clues: who found the clue, who gave the information to the sleuth (directly or indirectly), how the clue implicated someone or shed light on something, and where it was found (since I would probably have to refer to it later).

\begin{tabular}{|c|c|c|c|c|c|c|c|}
\hline$\Delta$ & A & $\mathrm{B}$ & C & D & $E$ & $\mathrm{~F}$ & G \\
\hline 1 & Number & Day & Clue & Finder & Xfer to Slueth & Suspect & Comment \\
\hline 2 & c001 & 2 & Gus found murdered & Mina & Adel (mom) & NA & Adel calls Marie: murder at work \\
\hline 3 & c002 & 2 & Mina a suspect & Adel & Adel (mom) & Mina & Adel tells Marie over dinner \\
\hline 4 & c003 & 3 & Gus is from money & John & John & NA & Elevator conversation \\
\hline 5 & c004 & 3 & Police determined it is murder & John & John & NA & Elevator conversation \\
\hline 6 & c005 & 7. & JoAnne from middle class & Ruby & Ruby & NA & Bridge Game 1 \\
\hline 7 & c006 & 7 & Safe in basement & Renato & Renato & Rolly & Bridge Game 1 \\
\hline 8 & $\mathrm{c} 007$ & 7 & JoAnne died of cancer & Heather & Heather & Robert & Bridge Game 1 \\
\hline 9 & c008 & 7 & Gus said safe was for quns, but he didn't hunt & Renato & Renato & Rolly & Bridge Game 1 \\
\hline 10 & c009 & 7 & Gus \& JoAnne had a dog & Renato & Renato & Mina & Bridge Game 1 \\
\hline 11 & c010 & & JoAnne was a master gardener & Heather & Heather & Rolly & Bridge Game 1 \\
\hline 12 & c011 & 10 & JoAnne's gardening area in the basement & Marie & Marie & Rolly & Smythe house visit 1 \\
\hline 13 & c012 & 10 & Safe in basement & Marie & Marie & Rolly & Smythe house visit 1 \\
\hline 14 & c013 & 10 & Gus had red 1965 Jaguar in mint condition & John & John & Rolly & Smythe house visit 1 \\
\hline 15 & c014 & 10 & Wood fragment and straw in safe & Marie & Marie & Rolly & Smythe house visit 1 \\
\hline 16 & c015 & 10 & Police suspect killer is family member & Police & John & Robert & Smythe house visit 1 \\
\hline 17 & c016 & 11 & Rolly listed as Gus' ICE & Police & John & Rolly & Phone call at work \\
\hline 18 & c017 & 11 & Rolly knew Gus in college (undergrad) & Police & John & Rolly & Phone call at work \\
\hline 19 & c018 & 12 & Attack started in the living room & Police & John & NA & Smythe house visit 2 \\
\hline 20 & c019 & 12 & Smythe house has security system & Police & John & NA & Smythe house visit 2 \\
\hline 21 & $\mathrm{c} 020$ & 12 & Victim knew the killer & Police & John & & Smythe house visit 2 \\
\hline 22 & c021 & 12 & Killer hit victim several times: weak person & Police & John & & Smythe house visit 2 \\
\hline 23 & c022 & 12 & Kill: passionate argument gone awry & Police & John & Robert & Smythe house visit 2 \\
\hline 24 & c023 & 13 & Suspect Mina. Low possibility. Love relationship? & Police & Police report & Mina & Report in case file \\
\hline 25 & c024 & 13 & Suspect Ryan. Low possibility. Old break in. & Police & Police report & Ryan & Report in case file \\
\hline
\end{tabular}

I had a "to do" list for my sleuth. Each item had a start (question is first asked) and stop (answer found). This helped me minimize "loose ends." The spreadsheet record helped me make sure my sleuth didn't complete a task before it actually started in the manuscript.

\begin{tabular}{|c|c|c|c|c|c|c|c|c|}
\hline 4 & A & $\mathrm{B}$ & C & D & $E$ & $\mathrm{~F}$ & G & $\mathrm{H}$ \\
\hline 1 & $\#$ & Item & Start & Stop & Comments & & & \\
\hline 2 & 0 & 0 Who killed Professor Smythe? & Day 00 & & & & & \\
\hline 3 & & 1 Find safe & Day 07 & Day 10 & Works with John Tyler & & & \\
\hline 4 & & 2 What was in the safe? & Day 07 & & d20 google Art returned. & & & \\
\hline 5 & & 3 Get financials: Mina & Day 14 & Day 16 & & & & \\
\hline 6 & & 4 Get financials: Ryan & Day 14 & Day 18 & & & & \\
\hline 7 & & 5 Get financials: Rolly & Day 14 & Day 18 & & & & \\
\hline 8 & & 6 Get financials: Robert & Day 14 & Day 17 & & & & \\
\hline 9 & & 7 Get financials: Smythe family & Day 14 & Day 17 & & & & \\
\hline 10 & 8 & 8 Find out if JoAnne's cancer treatment was top of the line or budget & Day 12 & Day 16 & & & & \\
\hline 11 & 9 & 9 Get police report on Ryan's break in attempt & Day 14 & Day 18 & what was he looking to steal? & & & \\
\hline 12 & 10 & $\begin{array}{l}\text { ask KU History staff and Mina Thompson what happened in February that might have } \\
\text { changed Professor Smythe's regard toward Thompson from normal to preferential }\end{array}$ & Day 16 & Day 16 & & & & \\
\hline 13 & 11 & 1 Ask Ann to find out from Grad Asst's what kind of taskmaster Smythe was. & Day 16 & Day 16 & & & & \\
\hline 14 & 12 & 2 Ask if Mina taking care of Gus' dog was reason for romantic rumor at KU & Day 16 & Day 16 & & & his & \\
\hline 15 & 13 & 3 Thank Smythe family for hotel recommendation: Langham Hotel & Day 17 & Day 17 & & & & \\
\hline 16 & 14 & 4 In the will, letter to Rolly. What does it say? & Day 17 & d22 partic & 17:ask trimble for copy. Trimble sa & ays get & ant. 19:p & ce trying. \\
\hline 17 & 15 & 5 Financial packets from William, Noble, and Annie. & Day 17 & Day 18 & & & & \\
\hline 18 & 16 & 6 William's schedule, was he invited to Gus \& JoAnne's wedding? Funeral? & Day 17 & Day 18 & & & & \\
\hline 19 & 17 & 7 Ask Mina about the gargoyle. & Day 17 & Day 18 & find out during Smythe interviews. & Ask An & k police & ask Mine \\
\hline 20 & 18 & 8 Get Annie Anheuser's alibi info (newspaper clipping) forwarded from Trimble. Verify. & Day 17 & Day 18 & & & & \\
\hline 21 & 19 & 9 Get William Smythe's alibi contacts from Trimble. Verify & Day 17 & Day 18 & d18:Marie gives Ann List. Verified & & & \\
\hline 22 & 20 & 0 Get Noble Smythe's alibi contacts from Trimble. Verify. & Day 17 & Day 18 & d18:Marie gives Ann List. Verified & & & \\
\hline 23 & 21 & 1 Ask Robert if he knows anything about the gargoyle & Day 18 & Day 20 & d18:Marie asks lawyers. & & & \\
\hline 24 & 22 & 2 Ask Robert if he (JoAnne) knew Rolly was listed as the ICE. & Day 18 & Day 20 & & & & \\
\hline 25 & 23 & Ask Annie what her rnminn nf ane nift was Ask Trimhle & กav 18 & กav 18 & & & & \\
\hline
\end{tabular}


All of these tools were helpful, but I found I was still not organized enough. My story covered about forty years and five states. I purchased Aeon Timeline software to help sort things out, but in the end it was easier for me to stick to spreadsheets than learn new software. (I do really want to learn Aeon sometime ... .) Later, I found having a timeline was helpful during rewrites. This was my timeline spreadsheet.

Maybe I should have said this earlier, but l'm not anal retentive. I was just drowning in data and didn't want to get anything wrong (mystery readers have a high standard). And, I work with spreadsheets in my day job. For me, they are a great tool.

After I had a good draft (version 14), I sent it to the chief of police (I played bridge with his mother) for review. He put a tremendous amount of energy into the review, but his feedback was difficult to take. He said my story was more like TV mysteries (where police

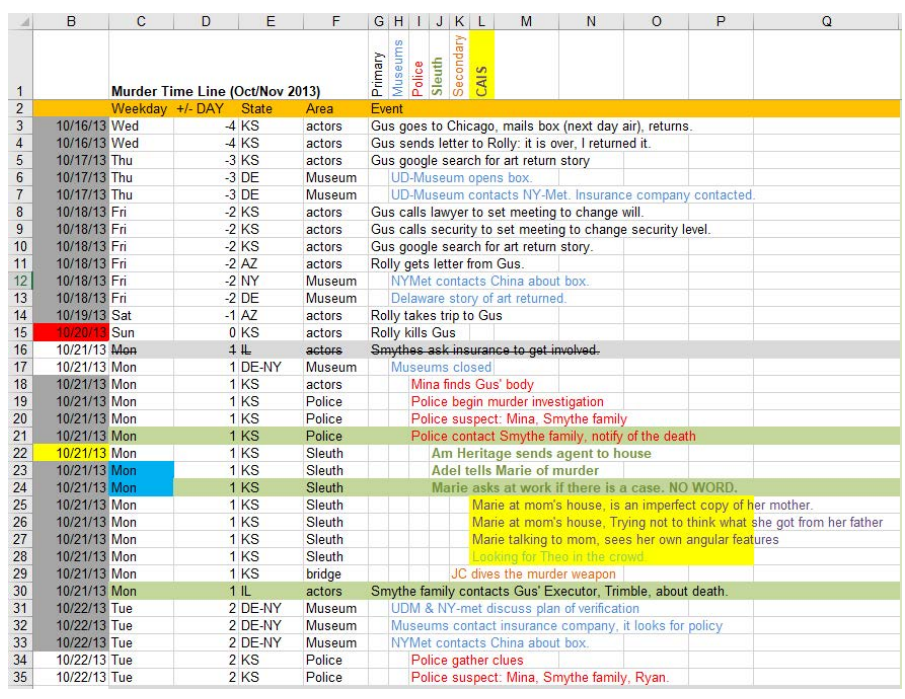
share information with people) than real-world crime solving (where everyone gives information to the police and they never share what they know). I made myself think of his feedback as research—how the detective process really works. I decided to rewrite the story to make it more realistic.

Another piece of beta-reader feedback that threw me for a loop was the fact that the museum pieces my thieves had stolen were from a China exhibit touring the United States during Mao's cultural revolution. There is no way Mao would have allowed valuable artifacts to leave the country-especially to go to the United States. It took a day for my subconscious to grind out the solution: the exhibit was touring in other countries, and when the Cultural Revolution hit, the world protected the art by keeping it on tour.

Oh. I forgot about ZimWiki. You see, I am scatterbrained. ZimWiki is software that lets you create your own version of Wikipedia (a very basic version). I first used it for Glass Road and now I use it for each book. After NaNoWriMo, I copied all backstory and research to ZimWiki and then added content as needed. Both word documents and spreadsheets seemed clumsy for the task. Here are a couple screenshots of controlled chaos.

\section{INTERVIEW TECHNIQUES}

\begin{tabular}{l} 
Index \\
\hline 265AD in Persia \\
Bookbasics \\
\pm Characters \\
Don't Forget \\
$\square$ Forensic Accounting \\
Education and Pay \\
Information used \\
Investigation steps \\
Personal Qualities \\
Questioning techniques \\
Types of cases \\
When someone is lying \\
Home \\
\pm Places \\
\pm Police \\
\pm Things \\
\pm Timeline \\
To Do List
\end{tabular}

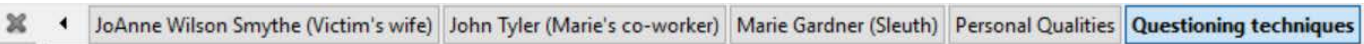
Questioning techniques

Created Wednesday 01 July 2015

\section{Psychologist tips}

- Build rapport. Think of it as just "good cop." Researchers have found that coming across as empathetic causes interrogation targets to open up more than when the interrogator is cold and accusatory. Many of the other techniques described in the journal depend on having a cooperative target, making this step all the more important. "The first thing you have to do is develop cooperation, rapport," Meissner says. "Once you have a cooperative person, the question is, How do I get all the info from them that I can?"

- Fill in the blank. To get that info, instead of asking direct questions, tell your target a story about what he or she did, leading the person to believe you already know what happened. As you provide the narrative, the guilty party will then supply details and corrections. This is called the Scharff technique, named for its developer, Hanns Scharff, a German interrogator during World War II. The technique was shown to elicit more information than direct questioning in a 2014 study. People interrogated using this method also tend to underestimate how much they are sharing.

- Surprise them. People who are interrogated often know they are under suspicion, so they practice their answers ahead of time. In addition, liars are under high cognitive strain as they try to keep their story straight and at the same time act calm and collected. If you ask them something unexpected, they often stumble when put on the spot-enabling you to catch them in a lie.

- Ask for the story backward. In contrast to what most people believe, truth tellers are more likely to add details and revise their stories over time, whereas liars tend to keep their stories the same. "Inconsistency is really just a fundamental ... 
The Origin of Things, Such as How the Items That Were Stolen Fit into Persia/China Relations and the History of the Silk Road:

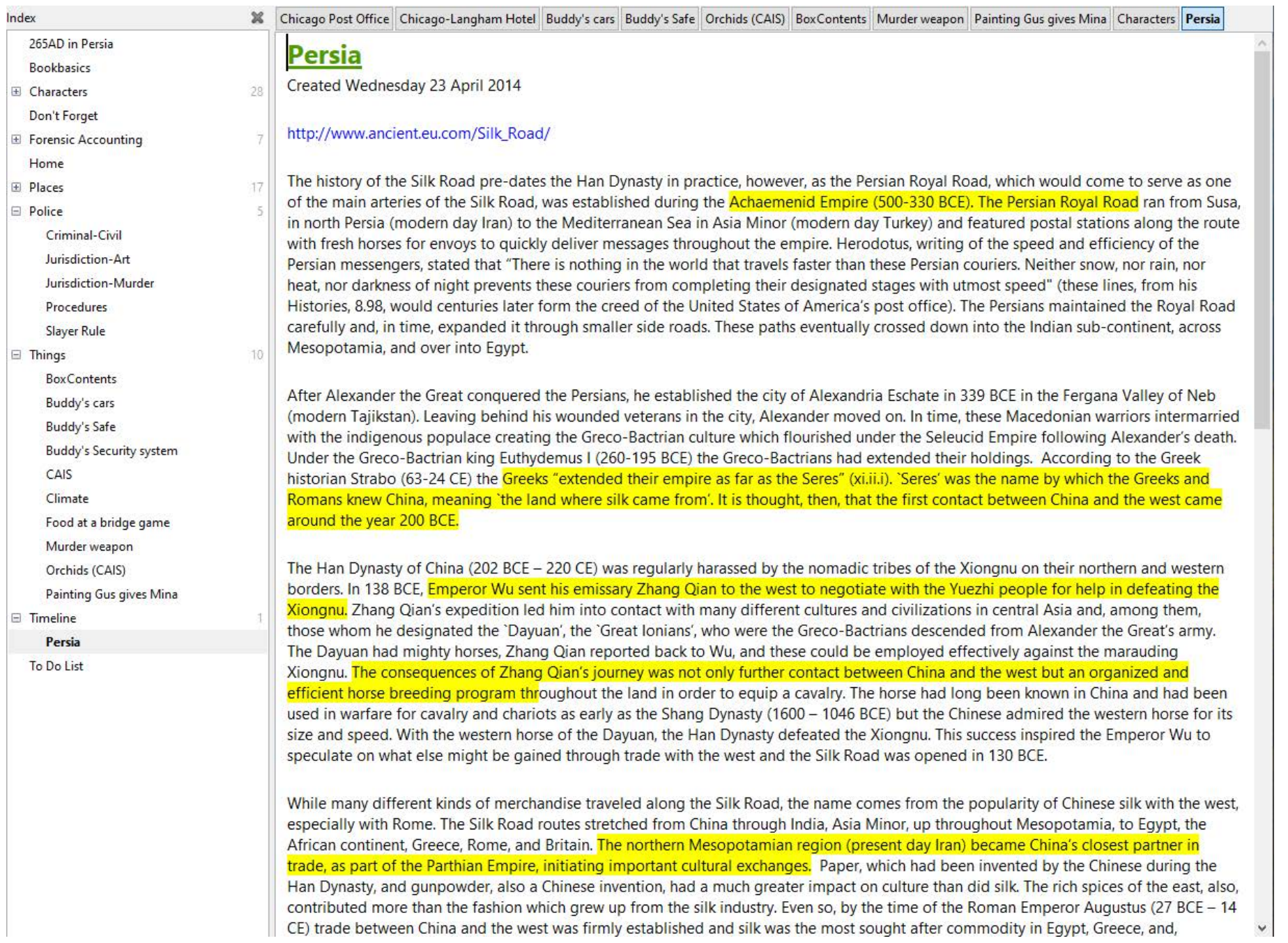

The extra time researching and organizing has added to my writing process has been worth it. I'm much more confident in the consistency and accuracy of my writing. I've also found I can create more depth. In The Glass Road, I didn't default to "some guys stole some art glass and it changed their lives." No. I knew that one-percenter beef baron's boy and the opportunistic bully stole Persia's marketing sampler-glass as it had never been worked before-and took it to China in 200 BCE to entice her emperors to establish the Silk Road that Persia's economy desperately needed. The theft of the glass changed the murder victim's course of study, his treatment of his graduate assistants, added millions of dollars in donations to universities, and returned artifacts to their rightful owners.

These days, people in my writing group accuse me of being a research junkie. I think l'd get no complaints from Ursula or Virginia.

\section{Resources:}

Aeon Timeline software. https://www.aeontimeline.com/users/creative-writers/.

Mystery Planning for Pantsers. My source is this link http://ticket2write.tripod.com/mysplot.html, but the original spreadsheet is from Jami Gold (www.jamigold.com).

NaNoWriMo Template. Simplified version: https://drive.google.com/file/d/1OqvsaMQzjVPfyzHW51QCgcYnto84nsn8/view.

ZimWiki. https://zim-wiki.org/. 